\title{
Effects of proteinate complex zinc on growth performance, hepatic and splenic trace elements concentrations, antioxidative function and immune functions in weaned piglets
}

\author{
Yue She', Qiang Huang', Defa Li', and Xiangshu Piao ${ }^{1, *}$
}

\begin{abstract}
* Corresponding Author: Xiangshu Piao Tel: +86-10-6273-3588, Fax: +86-10-6273-3688, E-mail: piaoxsh@cau.edu.cn
\end{abstract}

'State Key Laboratory of Animal Nutrition, Ministry of Agriculture Feed Industry Centre, ALLTECH-MAFIC Research Alliance, China Agricultural University, Beijing 100193, China

Submitted Nov 10, 2016; Revised Jan 6, 2017; Accepted Jan 9, 2017
Objective: To assess the effects of proteinate complex zinc (PC-Zn) on growth performance, antioxidative function, trace element concentrations and immune function in weaned piglets. Methods: Three hundred newly weaned barrows (Duroc $\times$ Landrace $\times$ Yorkshire), 28 days of age, were randomly allotted to 3 dietary groups of 5 replicate pens per group for 4 weeks of feeding. Experimental diets were: i) zinc deficient diet ( $\mathrm{ZnD}, 24 \mathrm{mg} / \mathrm{kg} \mathrm{Zn}$ supplementation from $\mathrm{ZnSO}_{4}$ ), ii) inorganic $\mathrm{Zn}$ diet supplemented with $120 \mathrm{mg} / \mathrm{kg}$ of $\mathrm{Zn}$ from $\mathrm{Zn}$ sulfate $\left(\mathrm{ZnSO}_{4}\right)$, and iii) organic $\mathrm{Zn}$ diet supplemented with $120 \mathrm{mg} / \mathrm{kg}$ of $\mathrm{Zn}$ from PC-Zn. The body weight of pigs were recorded at the beginning, at the middle and at the end of the experiment, and the amount of feed supplied each day was recorded. Five barrows from each dietary treatment group were selected to be anesthetized and euthanized at the end of the trial to determine the $\mathrm{Zn}, \mathrm{Cu}, \mathrm{Fe}$, and $\mathrm{Mn}$ concentrations, the hepatic metallothionein content, the levels of methane dicarboxylic aldehyde (MDA), $\mathrm{Mn}$, and $\mathrm{Cu} / \mathrm{Zn}$ superoxide dismutase (SOD), and glutathione peroxidase (GSH-Px) in the spleen, the levels of interleukin (IL)-2, IL-4, IL-10, interferon (IFN)- $\gamma$, CD3 ${ }^{+}$, $\mathrm{CD} 4^{+}$, and $\mathrm{CD} 8^{+} \mathrm{T}$ lymphocyte.

Results: The accumulation of $\mathrm{Zn}$ in the spleen, levels of SOD, GSH-Px, IL-4, IL-10, the proportions of $\mathrm{CD}^{+}$and $\mathrm{CD} 4^{+} \mathrm{T}$ lymphocyte, and the ratio of $\mathrm{CD}^{+} / \mathrm{CD}^{+} \mathrm{T}$ lymphocyte were increased by organic $\mathrm{Zn}$ supplementation compared to $\mathrm{ZnD}$, while the levels of MDA, IFN- $\gamma$, and proportion of $\mathrm{CD} 8^{+} \mathrm{T}$ lymphocyte were lowered.

Conclusion: These findings indicate that $\mathrm{Zn}$ can improve the antioxidant potential and immune functions of weaned piglets.

Keywords: Proteinate Complex Zinc; Growth Performance; Trace Elements Concentrations; Atioxidative Function; Immune Functions; Weaned Piglets

\section{INTRODUCTION}

Zinc $(\mathrm{Zn})$ is an important trace element involved in forming more than 300 kinds of metalloenzymes that affect biochemical processes of the whole body. Known functions of $\mathrm{Zn}$ include: regulating immune response, improving gastrointestinal digestion and interacting with the nervous system [1]. Many studies demonstrated $\mathrm{Zn}$ deficiency is common in several psychiatric disorders including induction of Alzheimer's disease [2]. Zinc sulfate $\left(\mathrm{ZnSO}_{4}\right)$ is one of the conventional supplemental forms of $\mathrm{Zn}$ in diets for pigs. However, organic $\mathrm{Zn}$ sources, such as proteinate complex $\mathrm{Zn}$ (PC-Zn), can reduce interactions between $\mathrm{Zn}$ and other minerals before and at the absorption site in the small intestine, which may result in higher bioavailability through protection from antagonists [3]. Nevertheless, the mechanisms underlying these effects have not been fully elucidated. Previous studies have suggested that improved growth performance of pigs may result from the role of $\mathrm{Zn}$ as a crucial component in the systemic antioxidative and immune 
network [4]. Work from our lab has demonstrated that inorganic $\mathrm{Zn}$ can reduce the incidence of diarrhea and ameliorate apoptosis in the small intestine of newly weaned piglets [5]. However, there is little published research on the effect of PC-Zn on growth performance, antioxidative and immune functions in pigs.

The liver is the primary storage organ of $\mathrm{Zn}$ and is the most responsive organ for antioxidative function and is sensitive to $\mathrm{Zn}$ deficiency. Recent study highlight $\mathrm{Zn}$ deficiency as one of the most consistent nutritional/biochemical reasons for liver diseases and $\mathrm{Zn}$ supplementation can protect liver from external and internal injury [6]. However, the mechanism of hepatoprotective properties of $\mathrm{Zn}$ has not been fully elucidated. In recent years, the availability of organic $\mathrm{Zn}$ sources for dietary supplementation has increased, but there exists controversy in the comparison of $\mathrm{PC}-\mathrm{Zn}$ and $\mathrm{ZnSO}_{4}$ related to liver functions in humans and animals. Ma et al [7] demonstrated that PC-Zn could improve hepatic antioxidant capacity and immune functions in weaned piglets compared with $\mathrm{ZnSO}_{4}$, whereas Hill et al [8] found there were no differences in the antioxidative function of the liver between $\mathrm{ZnSO}_{4}$ and $\mathrm{PC}-\mathrm{Zn}$. Moreover, the splenic $\mathrm{T}$ lymphocyte is the primary component of the immune reaction in spleen. Therefore, alterations of antioxidative function and $\mathrm{T}$ lymphocyte production in response to $\mathrm{Zn}$ supplementation can be reflective of the immunological effect of $\mathrm{Zn}$, which has not yet been studied.

The immune system is one of the main systems improved by $\mathrm{Zn}$ supplementation, and is considered to be one of the main reasons for effects of supplemental $\mathrm{Zn}$ on growth promotion. In the immune system, the spleen is the largest peripheral immune organ of the pig and plays a crucial role in maintaining immune homeostasis [9]. Studies have shown that $\mathrm{Zn}$ is associated with antioxidative and immune functions in the liver and serum, but it is less well known whether $\mathrm{Zn}$ has an immunoenhancement effect on the spleen [8]. Interleukin (IL) and interferon (IFN) cytokines play important roles in regulating splenic immune reactions and suppression of these can induce immune-mediated inflammatory diseases [10]. Therefore, it is necessary to test the effect of $\mathrm{Zn}$ supplementation and form on cytokine secretion in order to understand possible effects of $\mathrm{Zn}$ on immune function of the spleen.

The objectives of this study were to evaluate the effects of PC$\mathrm{Zn}$ on growth performance, trace mineral concentrations, levels of serous alkaline phosphatase (ALP), alanine transaminase (ALT) and aspartate transaminase (AST), antioxidative function - such as $\mathrm{Mn}$ and $\mathrm{Cu} / \mathrm{Zn}$ superoxide dismutase (SOD) and glutathione peroxidase (GSH-Px) and metallothionein (MT) concentration, and the immune functions of splenic $\mathrm{T}$ lymphocyte of piglets - such as the levels of interleukin (IL)-2, IL-4, IL-10, and IFN- $\gamma$, the proportions of $\mathrm{CD}^{+}, \mathrm{CD}^{+}, \mathrm{CD}^{+} \mathrm{T}^{+}$lymphocyte and the ratio of $\mathrm{CD}^{+} / \mathrm{CD}^{+} \mathrm{T}$ lymphocytes. Results from this study can provide a useful reference to understand the role of $\mathrm{Zn}$ in antioxidative function and immune response and reduce inorganic $\mathrm{Zn}$ environmental pollution.

\section{MATERIALS AND METHODS}

\section{Animals and experimental design}

The experimental protocol was approved by the Ethics Committee on the Use and Care of Animals, China Agricultural University (Beijing, China). Three hundred post-weaning barrows (28 days of age, Duroc $\times$ Landrace $\times$ Yorkshire) with an initial body weight of $7.19 \pm 0.19 \mathrm{~kg}$ were allotted to a completely randomized design with 3 dietary groups; each treatment was replicated 5 times with 20 pigs per replicate. Piglets were housed in partially steel-slatted concrete floored pens $(3.1 \mathrm{~m} \times 2.4 \mathrm{~m} \times 0.8 \mathrm{~m})$ and each pen was equipped with a stainless steel self-feeder and a nipple waterer. The feeding trial lasted for 28 days. Piglets had free access to both feed and drinking water throughout the trial. Three diets were formulated: A Zn deficient diet ( $24 \mathrm{mg} / \mathrm{kg} \mathrm{Zn}$ supplementation) mainly based on corn, soybean meal, soy protein concentrate, and whey powder was used as the control group $(\mathrm{ZnD})$. The other 2 diets were formulated based on the basal diet (without $\mathrm{Zn}$ ) additionally supplemented with $120 \mathrm{mg} / \mathrm{kg} \mathrm{Zn}$ as $\mathrm{ZnSO}_{4}$ or 120 $\mathrm{mg} / \mathrm{kg} \mathrm{Zn}$ as proteinate complex $\mathrm{Zn}$ (PC-Zn). The $\mathrm{ZnD}$ diet contained $26.50 \mathrm{mg} / \mathrm{kg}$ of $\mathrm{Zn}$. The PC-Zn, containing $16.7 \%$ of Zn, was supplied by Alltech Biotechnology, Inc. (Nicholasville, $\mathrm{KY}$, USA). The basal diet was formulated to meet the nutrient requirement recommended by the National Research and Council (NRC) 2012 [11] except Zn (Table 1).

\section{Growth performance}

The body weight of pigs were recorded at the beginning, at the middle and at the end of the experiment, and the amount of feed supplied each day was recorded.

\section{Sample collection and preparation}

Blood samples were obtained from the anterior vena cava at the end of the trial, centrifuged $(3,000 \times \mathrm{g})$ for $15 \mathrm{~min}$ at $4^{\circ} \mathrm{C}$ to collect serum. Serum samples were kept at $-70^{\circ} \mathrm{C}$ until analyzed. Five barrows (weighing closest to the average body weight for each pen) from each dietary treatment group (one barrow per pen) were selected to be anesthetized and euthanized at the end of the trial. The liver and spleen were removed immediately and rinsed with cold phosphate buffered saline ( $\mathrm{pH}$ 7.4). The samples were flash frozen in liquid nitrogen, and were stored at $-70^{\circ} \mathrm{C}$ before trace element and antioxidant enzyme activity analysis.

\section{Determination of mineral concentrations}

After thawing, liver and spleen samples were ground through an industrial meat grinder using a number 12 die before the samples were mixed and reground. The grinder was washed and dried between samples. Samples of $0.5 \mathrm{~g}$ each were wet digested according to the microwave digestion method of Hepp et al [12]. The $\mathrm{Zn}, \mathrm{Cu}, \mathrm{Fe}$, and $\mathrm{Mn}$ concentrations were determined using inductively coupled plasma-optical emissions spectrometry technology (Optima 8000, PerkinElmer Co., Berlin, Germany). 
Table 1. Chemical composition and nutrient levels of the basal diet (as-fed basis) 1)

\begin{tabular}{lc}
\hline Items & Percent \\
\hline Ingredient & \\
Corn & 63.99 \\
Soybean meal, 48\% crude protein & 13.00 \\
Soy protein concentrate, 63\% crude protein & 10.00 \\
Whey powder & 5.00 \\
Glucose & 3.00 \\
Soybean oil & 1.00 \\
Dicalcium phosphate & 1.30 \\
Calcium carbonate & 0.90 \\
Vitamin-mineral premix ${ }^{2)}$ & 0.50 \\
Salt & 0.30 \\
L-lysine-HCl (78\%) & 0.40 \\
DL-methionine & 0.26 \\
L-threonine & 0.27 \\
L-tryptophan & 0.08 \\
Nutrient levels) & \\
Digestible energy (kcal/kg) & 3,397 \\
Crude protein & 18.43 \\
Lysine & 1.30 \\
Methionine & 0.54 \\
Threonine & 0.96 \\
Tryptophan & 0.28 \\
Calcium & 0.72 \\
Total phosphorus & 0.60 \\
Zinc (mg/kg) & 26.50 \\
\hline The oter two & \\
\hline
\end{tabular}

1) The other two diets were provided based on this diet without supplying $\mathrm{Zn}$ at the expense of corn.

2) Supplied per kilogram diet: Vitamin A, 9,000 IU; vitamin $D_{3}, 3,000 \mathrm{IU}$; vitamin $E$, 64 $\mathrm{IU}$; vitamin $\mathrm{K}_{3}, 3 \mathrm{mg}$; vitamin $\mathrm{B}_{12}, 12 \mu \mathrm{g}$; riboflavin, $5.5 \mathrm{mg}$; pantothenic acid, $15 \mathrm{mg}$; niacin, $40 \mathrm{mg}$; choline chloride, $551 \mathrm{mg}$; folacin, $0.8 \mathrm{mg}$; thiamine $1.5 \mathrm{mg}$; pyridoxine 3 mg; biotin, $100 \mu g ; \mathrm{Mn}, 40$ mg; Fe, 100 mg; Cu, 150 mg; I, 0.3 mg; Se, $0.3 \mathrm{mg}$

${ }^{3)}$ All of the data are analyzed values except for digestible energy.

\section{Determination of hepatic enzyme activity and metallothionein}

The activities of ALP, ALT, and AST in serum were measured with a biochemical autoanalyzer (Hitachi 747, Hitachi Co., Tokyo, Japan). Liver samples were homogenized (Virtis homogenizer), diluted with $20-\mathrm{mM}$ Tris- $\mathrm{HCl}(\mathrm{pH} 7.4)$ and $0.1 \%$ peroxide-free Triton X-100 and centrifuged $(2,000 \times \mathrm{g})$ for $15 \mathrm{~min}$ at $4^{\circ} \mathrm{C}$. The supernatant was collected for the measurement of antioxidant enzymes activities. The hepatic MT content was examined by the $\mathrm{Cd} /$ hemoglobin affinity assay following the method of Eaton and Toal [13].

\section{Determination of antioxidant enzyme activity}

Spleen samples were homogenized (Virtis homogenizer), diluted with $20-\mathrm{mM}$ Tris- $\mathrm{HCl}$ (pH 7.4) and $0.1 \%$ peroxide-free Triton $\mathrm{X}-100$ and centrifuged $(2,000 \times \mathrm{g})$ for $15 \mathrm{~min}$ at $4^{\circ} \mathrm{C}$. The supernatant was collected for the measurement of antioxidant enzyme activities. The levels of MDA, Mn, and $\mathrm{Cu} / \mathrm{Zn} \mathrm{SOD}$, and GSHPx in the spleen were determined by commercial kits (Jiancheng Biochemical Reagent Co., Nanjing, China) using thiobarbituric acid reactive substances assay, xanthine oxidase method, and ammonium molybdenate chromogenic method, respectively.

\section{Determination of immunological parameters}

Preparation of splenic lymphocyte suspensions were accomplished according to the method of She et al [14]. The levels of IL-2, IL-4, IL-10, and IFN- $\gamma$ in the culture supernatants were determined by enzyme linked immunosorbent assay (ELISA) kits (Beijing Puerweiye Biotechnology Co. Ltd., Beijing, China). The ELISA method used to analyze the proportions of $\mathrm{CD}^{+}$, $\mathrm{CD}^{+}$, and $\mathrm{CD}^{+}$T lymphocyte.

\section{Statistical analysis}

Data were expressed as least square mean \pm standard deviation. One-way analysis of variance procedure in SPSS 21.0 software (SPSS Incorporated, Chicago, IL, USA) was used to assess statistical significances among treatments. A pen of pigs was served as the experimental unit for growth performance; individual pig was served as the experimental unit for other indexes. Statistical significance was determined by Duncan's test. Probability values of $p<0.05$ were considered statistically significant and $p<0.10$ considered a trend.

\section{RESULTS}

\section{Growth performance}

Table 2 shows the effects of $\mathrm{Zn}$ on nursery pig performance at $28 \mathrm{~d}$ postweaning. During d 0 to 14 , d 14 to 28 , and d 0 to 28 , average daily gain, average daily feed intake, or feed conversion ratio did not differ among treatments.

Table 2. Effect of zinc (Zn) on growth performance of weaned piglets (least square mean \pm standard deviation, $n=5$ per group)

\begin{tabular}{lrrr}
\hline Item & \multicolumn{1}{c}{ ZnD $^{1)}$} & \multicolumn{1}{c}{ ZnSO $_{4}$} & \multicolumn{1}{c}{ PC-Zn } \\
\hline BW (kg) & & & \\
d 0 & $7.1 \pm 0.5$ & $7.3 \pm 0.3$ & $7.2 \pm 0.7$ \\
d 14 & $9.2 \pm 0.5$ & $9.2 \pm 0.8$ & $9.4 \pm 1.2$ \\
d 28 & $14.0 \pm 1.9$ & $14.3 \pm 1.6$ & $14.6 \pm 1.9$ \\
ADG (g) & & & \\
0 to $14 d$ & $146.9 \pm 12.1$ & $150.8 \pm 15.4$ & $154.6 \pm 10.4$ \\
14 to $28 d$ & $393.1 \pm 33.4$ & $385.9 \pm 35.0$ & $389.9 \pm 30.2$ \\
0 to $28 d$ & $256.8 \pm 16.9$ & $265.9 \pm 18.5$ & $278.0 \pm 16.6$ \\
ADFI (g) & & & \\
0 to $14 d$ & $231.6 \pm 22.0$ & $241.2 \pm 15.4$ & $236.1 \pm 20.4$ \\
14 to $28 d$ & $422.2 \pm 38.4$ & $417.9 \pm 38.2$ & $430.8 \pm 39.3$ \\
0 to $28 d$ & $369.4 \pm 27.7$ & $354.5 \pm 21.5$ & $358.2 \pm 22.8$ \\
FCR & & & \\
0 to $14 d$ & $1.6 \pm 0.3$ & $1.6 \pm 0.3$ & $1.6 \pm 0.4$ \\
14 to $28 d$ & $1.1 \pm 0.2$ & $1.1 \pm 0.2$ & $1.2 \pm 0.3$ \\
0 to $28 d$ & $1.5 \pm 0.1$ & $1.4 \pm 0.1$ & $1.4 \pm 0.2$ \\
\hline
\end{tabular}

$B W$, body weight; $A D G$, average daily gain; $A D F I$, average daily feed intake; $F C R$, feed conversion ratio.

1) $\mathrm{ZnD}$, zinc deficient group; $\mathrm{ZnSO}_{4}$, zinc sulfate group (supplemented $120 \mathrm{mg} / \mathrm{kg}$ of $\mathrm{ZnSO}_{4}$ ): $\mathrm{PC}-\mathrm{Zn}$, proteinate complex zinc group (supplemented $120 \mathrm{mg} / \mathrm{kg}$ of $\mathrm{PC}-\mathrm{Zn}$ ). 
Hepatic and splenic mineral concentrations of $\mathrm{Zn}, \mathrm{Cu}, \mathrm{Fe}$, and $\mathrm{Mn}$

The splenic $\mathrm{Zn}$ concentration in $\mathrm{PC}-\mathrm{Zn}$ was greater $(\mathrm{p}<0.05)$ than in $\mathrm{ZnD}$ and $\mathrm{ZnSO}_{4}$ (Table 3). There were no differences between $\mathrm{ZnD}$ and $\mathrm{PC}-\mathrm{Zn}$ in the concentrations of $\mathrm{Cu}$ and $\mathrm{Fe}$ in the spleen, whereas both were decreased $(\mathrm{p}<0.05)$ in $\mathrm{ZnSO}_{4}$. The Mn concentration in the spleen of $\mathrm{ZnSO}_{4}$ and $\mathrm{PC}-\mathrm{Zn}$ animals was greater $(\mathrm{p}<0.05)$ than in $\mathrm{ZnD}$ animals. The hepatic $\mathrm{Zn}, \mathrm{Cu}$, and $\mathrm{Fe}$ concentrations in $\mathrm{PC}-\mathrm{Zn}$ group were greater $(\mathrm{p}<0.05)$ than those in $\mathrm{ZnSO}_{4}$ and $\mathrm{ZnD}$ groups (Table 3). The Mn concentration in PC$\mathrm{Zn}$ group was greater $(\mathrm{p}<0.05)$ than that in $\mathrm{ZnD}$ group.

Activities of alkaline phosphatase, alanine transaminase, and aspartate transaminase

The ALP content in PC-Zn group was greater $(\mathrm{p}<0.05)$ than that in $\mathrm{ZnSO}_{4}$ and $\mathrm{ZnD}$ groups (Table 4). No differences were observed in ALT or AST content among different treatments.

The methane dicarboxylic aldehyde level and activities of antioxidant enzymes

The splenic MDA concentration in PC-Zn was less $(\mathrm{p}<0.05)$ than in $\mathrm{ZnD}$ or $\mathrm{ZnSO}_{4}$ (Table 5). Supplementation with $\mathrm{Zn}$ decreased the hepatic MDA level $(\mathrm{p}<0.05)$ below the $\mathrm{ZnD}$ level (Table 5). Supplementation with $\mathrm{Zn}$ increased the splenic $\mathrm{Mn}$ SOD activity $(\mathrm{p}<0.05)$ above $\mathrm{ZnD}$. Activities of $\mathrm{Cu} / \mathrm{Zn} \mathrm{SOD}$ and GSH-Px were greater in $\mathrm{PC}-\mathrm{Zn}$ than in $\mathrm{ZnD}$ and $\mathrm{ZnSO}_{4}(\mathrm{p}<0.05)$ in the spleen. The activities of hepatic Mn-SOD and GSH-Px in PC-Zn group

Table 3. Effect of zinc ( $\mathrm{Zn})$ on mineral concentrations of weaned piglets (least square mean \pm standard deviation, $n=5$ per group)

\begin{tabular}{lcccc}
\hline Item $^{1)}$ & $\mathrm{Zn}(\mathbf{m g} / \mathbf{k g})$ & $\mathrm{Cu}(\mathbf{m g} / \mathbf{k g})$ & $\mathrm{Fe}(\mathbf{m g} / \mathbf{k g})$ & $\mathrm{Mn}(\mathbf{m g} / \mathbf{k g})$ \\
\hline Spleen & & & & \\
$\mathrm{ZnD}$ & $46.9 \pm 4.9^{\mathrm{c}}$ & $15.19 \pm 0.86^{\mathrm{a}}$ & $540.7 \pm 28.1^{\mathrm{a}}$ & $2.40 \pm 0.11^{\mathrm{b}}$ \\
$\mathrm{ZnSO}_{4}$ & $160.3 \pm 10.4^{\mathrm{b}}$ & $7.24 \pm 0.71^{\mathrm{b}}$ & $403.3 \pm 28.0^{\mathrm{b}}$ & $3.10 \pm 0.18^{\mathrm{a}}$ \\
$\mathrm{PC}-\mathrm{Zn}$ & $195.2 \pm 11.4^{\mathrm{a}}$ & $14.44 \pm 0.78^{\mathrm{a}}$ & $498.4 \pm 31.5^{\mathrm{a}}$ & $3.54 \pm 0.28^{\mathrm{a}}$ \\
Liver & & & & \\
$\mathrm{ZnD}$ & $47.47 \pm 4.62^{\mathrm{c}}$ & $8.48 \pm 0.55^{\mathrm{a}}$ & $145.42 \pm 8.73^{\mathrm{a}}$ & $2.14 \pm 0.20^{\mathrm{b}}$ \\
$\mathrm{ZnSO}_{4}$ & $67.88 \pm 4.14^{\mathrm{b}}$ & $6.39 \pm 0.49^{\mathrm{b}}$ & $122.29 \pm 10.02^{\mathrm{b}}$ & $2.42 \pm 0.22^{\mathrm{ab}}$ \\
$\mathrm{PC} \mathrm{Zn}$ & $80.22 \pm 5.85^{\mathrm{a}}$ & $8.29 \pm 0.96^{\mathrm{a}}$ & $139.10 \pm 8.74^{\mathrm{a}}$ & $2.65 \pm 0.23^{\mathrm{a}}$ \\
\hline
\end{tabular}

1) $\mathrm{ZnD}$, zinc deficient group; $\mathrm{ZnSO}_{4}$, zinc sulfate group (supplemented $120 \mathrm{mg} / \mathrm{kg}$ of $\mathrm{ZnSO}_{4}$ ); $\mathrm{PC}-\mathrm{Zn}$, proteinate complex zinc group (supplemented $120 \mathrm{mg} / \mathrm{kg}$ of PC-Zn). Values with different letters mean significant difference in the same column in the same organ $(p<0.05)$.

Table 4. Effects of zinc (Zn) on hepatic enzyme activities in weaned piglets (mean \pm standard deviation, $n=5$ per group)

\begin{tabular}{lccc}
\hline Item $^{1)}$ & ALP (IU/L) & ALT (IU/L) & AST (IU/L) \\
\hline $\mathrm{ZnD}$ & $23.46 \pm 2.18^{\mathrm{c}}$ & $23.55 \pm 1.12$ & $18.34 \pm 1.42$ \\
$\mathrm{ZnSO}_{4}$ & $26.78 \pm 1.15^{\mathrm{b}}$ & $23.07 \pm 1.59$ & $18.77 \pm 1.82$ \\
$\mathrm{PC}-\mathrm{Zn}$ & $32.43 \pm 2.06^{\mathrm{a}}$ & $26.09 \pm 2.29$ & $20.66 \pm 1.85$ \\
\hline
\end{tabular}

ALP, alkaline phosphatase; ALT, alanine aminotransferase; AST, aspartate transaminase. 1) $\mathrm{ZnD}$, zinc deficient group; $\mathrm{ZnSO}_{4}$, zinc sulfate group (supplemented $120 \mathrm{mg} / \mathrm{kg}$ of $\left.\mathrm{ZnSO}_{4}\right) ; \mathrm{PC}-\mathrm{Zn}$, proteinate complex zinc group (supplemented $120 \mathrm{mg} / \mathrm{kg}$ of PC-Zn). Values with different letters mean significant difference in the same column $(p<0.05)$.
Table 5. Effect of Zinc (Zn) on methane dicarboxylic aldehyde (MDA), Mn and Cu/Zn superoxide dismutase (SOD) and glutathione (GSH)-Px levels of weaned piglets (least square mean \pm standard deviation, $\mathrm{n}=5$ per group)

\begin{tabular}{ccccc}
\hline Item $^{1)}$ & $\begin{array}{c}\text { MDA } \\
(\mathrm{nmol} / \mathrm{mL})\end{array}$ & $\begin{array}{c}\mathrm{Mn} \mathrm{SOD} \\
(\mathrm{U} / \mathrm{mL})\end{array}$ & $\begin{array}{c}\mathrm{Cu} / \mathrm{Zn} \mathrm{SOD} \\
(\mathrm{U} / \mathrm{mL})\end{array}$ & $\begin{array}{c}\text { GSH-Px } \\
(\mathrm{U} / \mathrm{mL})\end{array}$ \\
\hline Spleen & & & & \\
ZnD & $5.02 \pm 0.34^{\mathrm{a}}$ & $3.42 \pm 0.31^{\mathrm{b}}$ & $77.95 \pm 6.12^{\mathrm{b}}$ & $119.02 \pm 6.54^{\mathrm{b}}$ \\
ZnSO & $4.73 \pm 0.24^{\mathrm{a}}$ & $4.06 \pm 0.31^{\mathrm{a}}$ & $82.77 \pm 6.69^{\mathrm{b}}$ & $122.18 \pm 4.07^{\mathrm{b}}$ \\
PC-Zn & $2.12 \pm 0.14^{\mathrm{b}}$ & $4.30 \pm 0.23^{\mathrm{a}}$ & $96.42 \pm 5.57^{\mathrm{a}}$ & $136.35 \pm 5.22^{\mathrm{a}}$ \\
Liver & & & & \\
ZnD & $4.34 \pm 0.28^{\mathrm{a}}$ & $10.23 \pm 0.67^{\mathrm{b}}$ & $45.50 \pm 3.41^{\mathrm{b}}$ & $121.51 \pm 4.50^{\mathrm{b}}$ \\
ZnSO $_{4}$ & $4.29 \pm 0.30^{\mathrm{a}}$ & $11.92 \pm 0.93^{\mathrm{b}}$ & $53.41 \pm 2.39^{\mathrm{a}}$ & $122.52 \pm 8.49^{\mathrm{b}}$ \\
$\mathrm{PC}^{\mathrm{b}} \mathrm{Zn}$ & $2.26 \pm 0.30^{\mathrm{b}}$ & $14.06 \pm 0.92^{\mathrm{a}}$ & $56.47 \pm 2.39^{\mathrm{a}}$ & $136.71 \pm 8.47^{\mathrm{a}}$ \\
\hline
\end{tabular}

1) $\mathrm{ZnD}$, zinc deficient group; $\mathrm{ZnSO}_{4}$, zinc sulfate group (supplemented $120 \mathrm{mg} / \mathrm{kg}$ of $\mathrm{ZnSO}_{4}$ ); PC-Zn, proteinate complex zinc group (supplemented $120 \mathrm{mg} / \mathrm{kg}$ of PC-Zn) Values with different letters mean significant difference in the same column in the same organ $(p<0.05)$.

were greater $(\mathrm{p}<0.05)$ than those in $\mathrm{ZnSO}_{4}$ and $\mathrm{ZnD}$ groups. The hepatic $\mathrm{Cu} / \mathrm{Zn}$ SOD activity in $\mathrm{Zn}$ supplemented groups was greater $(\mathrm{p}<0.05)$ than that in $\mathrm{ZnD}$ group (Table 5$)$.

\section{The metallothionein concentration}

The MT concentration in PC-Zn group was greater $(\mathrm{p}<0.05)$ than that in the other groups in the liver (Table 6).

\section{Levels of IL-2, IL-4, IL-10 and interferon- $\gamma$}

There was little evidence of differences in IL-2 concentrations between treatment groups (Table 7). Regardless of source, $\mathrm{Zn}$ supplementation increased IL-4 and IL-10 levels $(\mathrm{p}<0.05)$. The IFN- $\gamma$ level in PC- $\mathrm{Zn}$ was less than in $\mathrm{ZnD}$ and $\mathrm{ZnSO}_{4}(\mathrm{p}<0.05)$.

\section{Proportions of $\mathrm{CD}^{+}, \mathrm{CD}^{+}, \mathrm{CD8}^{+} \mathrm{T}$ lymphocyte and the}

Table 6. Effects of zinc (Zn) on metallothionein (MT) concentrations in weaned piglets (mean \pm standard deviation, $n=5$ per group).

\begin{tabular}{lc}
\hline Item $^{1)}$ & MT ( $\boldsymbol{\mu g} / \mathbf{g}$ liver) \\
\hline $\mathrm{ZnD}$ & $315.05 \pm 22.66^{\mathrm{c}}$ \\
$\mathrm{ZnSO}_{4}$ & $516.03 \pm 37.29^{\mathrm{b}}$ \\
$\mathrm{PC}-\mathrm{Zn}$ & $706.29 \pm 18.62^{\mathrm{a}}$ \\
\hline
\end{tabular}

1) $\mathrm{ZnD}$, zinc deficient group; $\mathrm{ZnSO}_{4}$, zinc sulfate group (supplemented $120 \mathrm{mg} / \mathrm{kg}$ of $\mathrm{ZnSO}_{4}$ ); PC-Zn, proteinate complex zinc group (supplemented $120 \mathrm{mg} / \mathrm{kg}$ of PC-Zn). Values with different letters mean significant difference in the same column $(p<0.05)$.

Table 7. Effect of zinc (Zn) on splenic interleukin (IL)-2, IL-4, IL-10, and interferon (IFN) $-\gamma$ levels of weaned piglets (least square mean \pm standard deviation, $n=5$ per group)

\begin{tabular}{lrrrc}
\hline Item $^{1)}$ & IL-2 (pg/mL) & IL-4 (pg/mL) & IL-10 (pg/mL) & IFN- $\gamma(\mathbf{n g} / \mathbf{m L})$ \\
\hline $\mathrm{ZnD}$ & $600.57 \pm 19.24$ & $90.45 \pm 4.50^{\mathrm{c}}$ & $84.56 \pm 4.53^{\mathrm{b}}$ & $1.20 \pm 0.05^{\mathrm{a}}$ \\
$\mathrm{ZnSO}_{4}$ & $615.82 \pm 24.60$ & $100.36 \pm 5.92^{\mathrm{b}}$ & $93.33 \pm 3.79^{\mathrm{a}}$ & $1.12 \pm 0.06^{\mathrm{a}}$ \\
$\mathrm{PC}-\mathrm{Zn}$ & $619.17 \pm 20.08$ & $112.94 \pm 6.64^{\mathrm{a}}$ & $95.52 \pm 6.15^{\mathrm{a}}$ & $1.02 \pm 0.04^{\mathrm{b}}$ \\
\hline
\end{tabular}

1) $\mathrm{ZnD}$, zinc deficient group; $\mathrm{ZnSO}_{4}$, zinc sulfate group (supplemented $120 \mathrm{mg} / \mathrm{kg}$ of ZnSO4); PC-Zn, proteinate complex zinc group (supplemented $120 \mathrm{mg} / \mathrm{kg}$ of PC-Zn). Values with different letters mean significant difference in the same column $(p<0.05)$. 
ratio of $\mathrm{CD}^{+} / \mathrm{CD8}^{+} \mathrm{T}$ lymphocyte

Proteinate complex $\mathrm{Zn}$ supplementation increased $(\mathrm{p}<0.05)$ the proportions of $\mathrm{CD}^{+}$and $\mathrm{CD}^{+}$and decreased proportion of $\mathrm{CD} 8^{+}$ T lymphocytes compared to $\mathrm{ZnD}$ and $\mathrm{ZnSO}_{4}$ (Table 8). Therefore, the ratio of $\mathrm{CD}^{+} / \mathrm{CD}^{+} \mathrm{T}$ lymphocytes was also increased in PC$\mathrm{Zn}$ versus $\mathrm{ZnD}$ and $\mathrm{ZnSO}_{4}$.

\section{DISCUSSION}

The nutritional importance of $\mathrm{Zn}$ is well recognized [15]. However, several mechanisms related to dietary $\mathrm{Zn}$ effects in the spleen and liver are still unclear, particularly for PC-Zn. Here, we have investigated retentive mineral concentrations, serum biochemistry parameters related to hepatic enzyme activity, splenic and hepatic antioxidant enzyme activity, hepatic MT level, secretion of inflammatory cytokines, $\mathrm{T}$ lymphocyte subsets and the interactions of $\mathrm{Zn}$ with other ions in order to better understand the positive effects of $\mathrm{Zn}$ on liver function in piglets.

Dietary $\mathrm{Zn}$ supplementation in this experiment was within the range of optimal doses reported by recent publications $[7,8]$. The current study demonstrated that $\mathrm{Zn}$ concentration in the spleen was greater after $\mathrm{Zn}$ supplementation. Furthermore, $\mathrm{Zn}$ deposition in the spleen was greater from the PC- $\mathrm{Zn}$ than from $\mathrm{ZnD}$ and $\mathrm{ZnSO}_{4}$. It has been adequately verified that there is antagonism between $\mathrm{Zn}$ and $\mathrm{Cu}$ and $\mathrm{Zn}$ and $\mathrm{Fe}$ [16]. Noticeably, $\mathrm{Cu}$ and Fe were poorly absorbed after supplementing $\mathrm{ZnSO}_{4}$ in this experiment. Interestingly, deposition of $\mathrm{Cu}$ and $\mathrm{Fe}$ in the spleen did not differ between PC- $\mathrm{Zn}$ and $\mathrm{ZnD}$ groups, suggesting that the uptake of PC-Zn did not antagonize $\mathrm{Cu}$ or Fe absorption. Specifically, organic $\mathrm{Zn}$ sources, such as proteinates and amino acid chelates, can protect $\mathrm{Zn}$ from interactions before and at the absorption site of the other minerals in the small intestine, which may result in higher bioavailability and reduced antagonisms [17].

$\mathrm{Zn}$ homeostasis influences the metabolism of the other trace elements, $\mathrm{Cu}, \mathrm{Fe}, \mathrm{Mn}$, and $\mathrm{Se}$. The liver represents a fast-exchangeable $\mathrm{Zn}$ pool with a key role in the metabolism of $\mathrm{Zn}$ and the other trace elements [18]. The current study showed that $\mathrm{Zn}$ concentration in liver was greater after $\mathrm{Zn}$ supplementation. Furthermore, $\mathrm{Zn}$ retention in liver was greater from PC-Zn than from $\mathrm{ZnSO}_{4}$. Differential absorption and transport between PC-

Table 8. Effect of zinc (Zn) on $\mathrm{CD}^{+}, \mathrm{CD}^{+}, \mathrm{CD} 8^{+} \mathrm{T}$ lymphocytes proportions and ratio of $\mathrm{CD}^{+} / \mathrm{CD}^{+} \mathrm{T}$ lymphocytes of weaned piglets (least square mean \pm standard deviation, $\mathrm{n}=5$ per group)

\begin{tabular}{lcccc}
\hline Item $^{1)}$ & $\mathrm{CD}^{+}(\%)$ & $\mathrm{CD}^{+}(\%)$ & $\mathrm{CD}^{+}(\%)$ & $\mathrm{CD}^{+} / \mathrm{CD}^{+}$ \\
\hline $\mathrm{ZnD}$ & $42.44 \pm 2.03^{\mathrm{b}}$ & $25.77 \pm 2.37^{\mathrm{c}}$ & $24.68 \pm 0.94^{\mathrm{a}}$ & $1.04 \pm 0.10^{\mathrm{c}}$ \\
$\mathrm{ZnSO}_{4}$ & $46.08 \pm 3.45^{\mathrm{b}}$ & $31.35 \pm 2.58^{\mathrm{b}}$ & $22.07 \pm 1.06^{\mathrm{a}}$ & $1.42 \pm 0.09^{\mathrm{b}}$ \\
$\mathrm{PC}-\mathrm{Zn}$ & $58.99 \pm 2.26^{\mathrm{a}}$ & $39.28 \pm 2.67^{\mathrm{a}}$ & $19.73 \pm 1.02^{\mathrm{b}}$ & $1.99 \pm 0.05^{\mathrm{a}}$ \\
\hline
\end{tabular}

1) $\mathrm{ZnD}$, zinc deficient group; $\mathrm{ZnSO}_{4}$, zinc sulfate group (supplemented $120 \mathrm{mg} / \mathrm{kg}$ of $\left.\mathrm{ZnSO}_{4}\right)$; $\mathrm{PC}-\mathrm{Zn}$, proteinate complex zinc group (supplemented $120 \mathrm{mg} / \mathrm{kg}$ of PC-Zn). Values with different letters mean significant difference in the same column $(p<0.05)$.
$\mathrm{Zn}$ and $\mathrm{ZnSO}_{4}$ sources has been proposed [19], but further studies are still needed to test the specifics of PC-Zn transport. Copper is an essential trace element encountered in many proteins such as $\mathrm{Cu} / \mathrm{Zn} \mathrm{SOD}$ and MT. Liver represents an important $\mathrm{Cu}$ pool. It has been demonstrated there is antagonism between $\mathrm{Zn}$ and $\mathrm{Cu}$ and $\mathrm{Zn}$ and $\mathrm{Fe}$ [20]. Our data indicate $\mathrm{Fe}$ and $\mathrm{Cu}$ were poorly absorbed after supplementing $\mathrm{ZnSO}_{4}$. It is interesting that retention of $\mathrm{Cu}$ and $\mathrm{Fe}$ in liver did not differ between PC-Zn group and $\mathrm{ZnD}$ group, suggesting that the uptake of PC-Zn did not antagonize $\mathrm{Cu}$ or $\mathrm{Fe}$ absorption. This implies a better utilization of $\mathrm{Zn}, \mathrm{Cu}$, and Fe from the PC- $\mathrm{Zn}$ compared with $\mathrm{ZnSO}_{4}$.

The ALP is a $\mathrm{Zn}$-dependent enzyme which is mainly synthesized by liver and bone. The ALP plays a key role in skeletal development and, therefore, has direct effects on growth performance of animals [16]. Sun et al [21] reported ALP activity in the plasma of $\mathrm{Zn}$ deficient rats was significantly decreased compared with $\mathrm{Zn}$ supplemented rats. It has also been reported that the ALP activity of pigs fed dietary chitosan-Zn chelate was greater than the activity in pigs fed $\mathrm{Zn}$ deficient diets [7]. In this study, the ALP activity in the PC-Zn group was greater than in the other groups. This may be because that $\mathrm{Zn}$ is an essential component of ALP. Since there is a strong correlation between $\mathrm{Zn}$ concentration and ALP activity, our data imply a positive effect of PC$\mathrm{Zn}$ on ALP secretion. It has been demonstrated that increased ALP in response to $\mathrm{Zn}$ supplementation could enhance the osteoblast proliferation and bone forming capacity of bone marrow, which may consequently improve the retention of calcium and phosphorus in the bone [22]. Additionally, it is well documented that $\mathrm{Zn}$ deficiency can result in reduced synthesis of ALP from sialaden, which may subsequently lead to appetite suppression [23] thus reducing growth performance.

Weaning is known to cause significant stress and supplementing $\mathrm{Zn}$ into the diet can improve enzyme activities against oxidative stress. Malondialdehyde is an index of lipid peroxidation (LPO), which can reflect the degree of hepatocyte membrane damage and LPO in the liver. A recent study showed that MDA levels in serum and liver were reduced in broilers fed diets containing organic zinc nanoparticles compared to broilers in the $\mathrm{Zn}$ deficient group [4]. Our findings suggest a role of PC-Zn in reducing LPO in piglets. Since evidence indicates that hepatic LPO plays an important role in the pathogenesis of hepatic diseases of rats such as fibrogenesis and that $\mathrm{Zn}$ mitigates the process of LPO [24], this supports our hypothesis that PC-Zn contributes to inhibition of LPO in piglets. Additionally, our result also implies Zn deficiency by itself could result in greater LPO in piglets, which indirectly suggests an enhanced production of oxygen free radicals in piglets.

Improving oxidative resistance is one of the routes that $\mathrm{Zn}$ is known to benefit the immune system and health of piglets $[7,8]$. Malondialdehyde can exacerbate the degree of T-cell membrane damage and can indirectly reflect the antioxidant capacity of the spleen. Our current study showed that supplementation with 
PC-Zn reduced MDA concentration in the spleen, in agreement with previous studies carried out on serum and liver [7]. The $\mathrm{ZnSO}_{4}$ supplementation did not decrease splenic MDA concentration, perhaps due to the competition between $\mathrm{Zn}$ and Fe for transferrin, which resulted in increased concentrations of $\mathrm{Fe}^{2+}$ in the spleen, increasing LPO. Activity levels of $\mathrm{Cu} / \mathrm{Zn}$ SOD and GSH-Px were greater in PC- $\mathrm{Zn}$ compared to $\mathrm{ZnD}$ and $\mathrm{ZnSO}_{4}$ groups, suggesting that $\mathrm{PC}-\mathrm{Zn}$ can improve oxidative resistance more efficiently than inorganic $\mathrm{Zn}$, consistent with the observations of Hill et al [8].

There is still controversy whether hepatic SOD and GSH-Px levels differ after $\mathrm{PC}-\mathrm{Zn}$ or $\mathrm{ZnSO}_{4}$ supplementation in piglets. Ma et al [7] found that dietary Chitosan-Zn chelate showed higher $\mathrm{Cu} / \mathrm{Zn}$ SOD and GSH-Px activities in liver compared with zinc deficient group, while Hill et al [8] and Martin et al [25] reported there was no difference in antioxidative function in liver between $\mathrm{ZnSO}_{4}$ and PC-Zn. Our study showed that the hepatic $\mathrm{Mn}$ - and $\mathrm{Cu} / \mathrm{Zn}$ SOD activities in PC-Zn group were greater than those in $\mathrm{ZnSO}_{4}$ and $\mathrm{ZnD}$ groups. Also, the $\mathrm{Mn}$ and $\mathrm{Zn}$ retention in liver was greater in PC- $\mathrm{Zn}$ group than in $\mathrm{ZnD}$ group. The $\mathrm{O}_{2}^{-{ }^{-}}$ is a type of reactive oxygen species (ROS), and highly increased ROS concentrations play pathophysiological roles in the processes of liver diseases. The dismutation reaction of superoxide is catalyzed by SOD and $\mathrm{Mn}$ and $\mathrm{Cu}$ and $\mathrm{Zn}$ are essential components of $\mathrm{Mn}$ - and $\mathrm{Cu} / \mathrm{Zn} \mathrm{SOD}$, respectively. Decreased activity of SOD in the $\mathrm{ZnD}$ group observed in this study may be due to the depletion of this enzyme in dismutation reactions. Glutathione is considered to be a crucial biomarker in LPO and is important in maintaining the normal cellular redox state $[4,7]$. The hepatic GSH-Px activity depends on the balance between the contents of GSH and glutathione disulfide, which can scavenge excess hydrogen peroxide and lipid peroxides in response to antioxidative function [26]. Our study suggests beneficial effects due to GSH-Px activity in liver may be one of the antioxidative function mechanisms resulting from PC-Zn supplementation for piglets. In this respect, we extrapolated that the increased activities of SOD and GSH-Px after PC-Zn supplementation observed in this experiment may serve to reduce active ROS, which has a significant effect on improving antioxidative function.

Metallothionein is the most abundant $\mathrm{Zn}$ storage protein and is mainly involved in $\mathrm{Zn}$ ion homeostasis, detoxification of heavy metals and antioxidative function [27]. In the current study, the MT concentration in PC-Zn group was greater than that in the other treatments. This demonstrated the role of MT in capturing PC-Zn in liver, which agrees with reports from previous investigations [8]. Metallothionein is an excellent scavenger of ROS, such as hydroxyl radicals, which firstly damage the MT molecule and thus it protects the sensitive parts of the cell.

Splenic T lymphocyte concentration is an essential factor in maintaining immune homeostasis of the spleen and the fluctuations can indicate cellular immunologic status. Therefore $\mathrm{T}$ lymphocyte concentration was measured in this study to evaluate the splenic immune status of piglets following $\mathrm{Zn}$ supplementation. Interleukin-2, IL-4, IL-10, and IFN- $\gamma$ are typical multifunctional cytokines in the regulation of immune reaction and inflammation. Interleukin- 4 and IL-10 are anti-inflammatory cytokines which are mainly secreted by activated $\mathrm{T}$ lymphocytes [28]. So far, no study has assessed the effects of $\mathrm{Zn}$ on the splenic IL- 4 or IL-10 secretion of pigs. For the first time, this study has shown that $\mathrm{Zn}$ supplementation increased the concentrations of IL-4 and IL-10. Increased production of IL- 4 and IL-10 implies better protection from potential causes of inflammation. In addition, it has been recognized that $\mathrm{Zn}$ can contribute to expediting wound healing and we deduced that it may be due to a functional association with IL-4 and IL-10 secretion, which can inhibit infection of the wound. Furthermore, antioxidative function was correlated to faster and better wound healing in the body. Therefore, we extrapolated that improved antioxidative function and IL-4 and IL-10 levels after Zn supplementation cooperated in improving healing. Moreover, IL-4 and IL-10 are considered as important growth factors for antigen-activated T lymphocytes and are key cytokines in T lymphocyte proliferation cycle. Our result revealed that $\mathrm{Zn}$ supplementation increased the levels of IL-4 and IL-10. Therefore, we deduced that the increased IL-4 and IL-10 levels in Zn supplementation groups might be associated with an enhancement of $\mathrm{T}$ lymphocyte proliferation. This phenomenon formed a positive feedback regulatory mechanism, indicating a strong function of $\mathrm{Zn}$ supplementation on the immune system.

Compared with IL- 4 and IL-10, IFN- $\gamma$ is a proinflammatory cytokine and is also secreted by activated $\mathrm{T}$ lymphocytes. Our experiment indicated that $\mathrm{Zn}$ supplementation decreased IFN- $\gamma$ level. Recent data, however, showed that $\mathrm{Zn}$ has a stimulative effect on the production of IFN- $\gamma$ in the serum of rats. This contradiction may be due to the immune response of IFN- $\gamma$ in models of inflammation, as opposed to this study where inflammation was not a pathological condition. It has been shown IFN- $\gamma$ can modulate chemokine secretion in response to the other cytokines and affect cellular adhesion and transmigration. Thus, our result suggests that the reduced level of IFN- $\gamma$ after $\mathrm{Zn}$ supplementation can decrease the risk of inflammation. Also, IFN- $\gamma$ can downregulate the expression of surface adhesion factors in lymphocytes. The decreased level of IFN- $\gamma$ in PC-Zn group suggests that $\mathrm{Zn}$ can improve the migration and adhesion abilities of T lymphocytes indirectly.

The $\mathrm{CD}^{+}$molecule reacts with all mature T-cells and it is a common surface marker for T lymphocytes. Thus, the increased proportion of $\mathrm{CD}^{+} \mathrm{T}$ lymphocytes in the PC-Zn supplementation group reflects the rising total number of periphery mature T lymphocytes. Liu et al [19] reported that the proportion of jejunal epithelium $\mathrm{CD}^{+} \mathrm{T}$-cells of piglets increased gradually with PC-Zn supplementation, which is reflected in our result. This may indicate the maturation of splenic $T$ lymphocyte related immune mechanisms after $\mathrm{Zn}$ supplementation, which is essen- 
tial for normal T-cell function. T helper (Th) cells, such as $\mathrm{CD} 4^{+}$ $\mathrm{T}$ lymphocytes, play a key role in the intermediate processes of the immune response and affect the activation of immunocytes; this kind of enhancement implied that the immunocyte would be activated following Zn supplementation. T helper cells differentiate into Th1 and Th2 effector cells after activation. The Th1 subsets mainly include $\mathrm{CD} 4^{+} \mathrm{T}$ lymphocytes, which secrete inflammation related cytokines (such as IL-2 and IFN- $\gamma$ ). Th2 subsets differentiate by secreting cytokines include IL- 4 and IL- 10 . Both Th1 and Th2 subsets induce cell-mediated immunoreaction [29]. Accordingly, the rise of $\mathrm{CD}^{+} \mathrm{T}$ lymphocyte proportions with $\mathrm{Zn}$ supplementation reflected the increases of IL-2 and that was why the enhancement of $\mathrm{CD} 4^{+} \mathrm{T}$ lymphocytes was in line with IL-2. CD8 ${ }^{+} \mathrm{T}$ lymphocyte is mainly a cytotoxic T lymphocyte, which can kill the target cells directly. Hence, the decreased proportion of $\mathrm{CD}^{+} \mathrm{T}$ lymphocyte in PC-Zn suggests less cytotoxin accumulated and positive effects of $\mathrm{Zn}$ on cellular immunity. Notably, the ratio of $\mathrm{CD}^{+} / \mathrm{CD}^{+}{ }^{+}$lymphocyte can reflect cellular immune state of animals and the increased ratio in PC-Zn indicated a state of promotion of immunity in this study.

In our study, Zn supplementation, especially for PC-Zn, increased the proportions of $\mathrm{CD}^{+}, \mathrm{CD}^{+} \mathrm{T}$ lymphocytes and the ratio of $\mathrm{CD}^{+} / \mathrm{CD}^{+} \mathrm{T}$ lymphocytes, while the proportion of $\mathrm{CD} 8^{+}$ $\mathrm{T}$ lymphocyte decreased. These results demonstrated that $\mathrm{Zn}$ supplementation improved the maturity of $\mathrm{T}$ lymphocytes and stabilized the dynamic balance among $\mathrm{T}$ lymphocyte subsets. In addition, activated $\mathrm{CD} 4^{+} \mathrm{T}$ lymphocytes are considered to produce IL- 4 that can drive Th2 differentiation in some settings [30]. As this early IL-4 is the key determinant for the differentiation of Th2 cells, higher production of IL-4 following $\mathrm{Zn}$ supplementation in our experiment could be tightly regulated so as to avoid biased Th2 responses. This may also benefit cellular immunity of weaned piglets. Furthermore, glutathione is known to enhance the production and synthesis of Th1 associated cytokines. This may be the reason that the levels of IL- 4 and IL-10 increased as GSH-Px level increased in Zn supplementation group in our experiment.

In conclusion, PC-Zn supplementation improved splenic T lymphocyte immune functions of weaned piglets, increased the retention of $\mathrm{Zn}, \mathrm{Cu}, \mathrm{Mn}$, and $\mathrm{Fe}$ in the spleen, increased antioxidative function and the proportions of $\mathrm{T}$ lymphocyte subsets, indicating that PC-Zn supplementation favors the splenic antioxidative and cellular immune states of piglets. Also, PC-Zn supplementation improved scavenging of hepatic free radicals resulting in increased antioxidative function. The mechanism of hepatoprotective properties of $\mathrm{Zn}$ can be attributed to the following: zinc can improve ALP level, inhibit LPO, increase the antioxidant enzyme activities and MT concentration in hepatic cells, and elevate essential trace mineral components of $\mathrm{Mn}$ - and $\mathrm{Cu} / \mathrm{Zn} \mathrm{SOD}$.

\section{CONFLICT OF INTEREST}

We certify that there is no conflict of interest with any financial organization regarding the material discussed in the manuscript.

\section{ACKNOWLEDGMENTS}

This study was supported by a grant from the National Natural Science Fund of China (31372316). We appreciate the generous gifts of the organic $\mathrm{Zn}$ from Alltech Biotechnology, Inc. (Nicholasville, KY, USA).

\section{REFERENCES}

1.Koo OJ, Park SJ, Lee C, et al. Production of mutated porcine embryos using zinc finger nucleases and a reporter-based cell enrichment system. Asian-Australas J Anim Sci 2014;27:324-9.

2.Grønli O, Kvamme JM, Friborg O, Wynn R. Zinc deficiency is common in several psychiatric disorders. PLoS One 2013;8:e82793.

3.Lebel A, Matte JJ, Guay F. Effect of mineral source and mannan oligosaccharide supplements on zinc and copper digestibility in growing pigs. Arch Anim Nutr 2014;68:370-84.

4.Zhao CY, Tan SX, Xiao XY, et al. Effects of dietary zinc oxide nanoparticles on growth performance and antioxidative status in broilers. Biol Trace Elem Res 2014;160:361-7.

5.Wang X, Ou D, Yin JD, Wu G, Wang J. Proteomic analysis reveals altered expression of proteins related to glutathione metabolism and apoptosis in the small intestine of zinc oxide- supplemented piglets. Amino Acids 2009;37:209-18.

6.O'Halloran TV, Kebede M, Philips SJ, Attie AD. Zinc, insulin, and the liver: a ménage à trois. J Clin Invest 2013;123:4136-9.

7.Ma Y, Huang Q, Lv M, et al. Chitosan-Zn chelate increases antioxidant enzyme activity and improves immune function in weaned piglets. Biol Trace Elem Res 2014;158:45-50.

8.Hill GM, Mahan DC, Jolliff JS. Comparison of organic and inorganic zinc sources to maximize growth and meet the zinc needs of the nursery pig. J Anim Sci 2014;92:1582-94.

9.Bakhiet M, Taha S. A novel nervous system-induced factor inducing immune responses in the spleen. Immunol Cell Biol 2008;86:688-99.

10. Elenkov IJ, Iezzoni DG, Daly A, Harris AG, Chrousos GP. Cytokine dysregulation, inflammation and well-being. Neuroimmunomodulation 2005;12:255-69.

11. Committee on Nutrient Requirements of Swine, National Research Council. Nutrient requirements of swine. 11th ed. Washington, DC: National Academy Press; 2012.

12. Hepp NM, Mindak WR, Cheng J. Determination of total lead in lipstick: development and validation of a microwave-assisted digestion, inductively coupled plasma-mass spectrometric method. J Cosmet Sci 2009;60:405-14.

13. Eaton DL, Toal BF. Evaluation of the Cd/hemoglobin affinity assay for the rapid determination of metallothionein in biological tissues. Toxicol Appl Pharm 1982;66:134-42. 
14. She Y, Wang N, Chen C, et al. Effects of aluminum on immune functions of cultured splenic T and B lymphocytes in rats. Biol Trace Elem Res 2012;147:246-50.

15. Pieper R, Martin L, Schunter N, et al. Impact of high dietary zinc on zinc accumulation, enzyme activity and proteomic profiles in the pancreas of piglets. J Trace Elem Med Biol 2015;30:30-6.

16. Keen CL, Reinstein NH, Goudey-Lefevre J, et al. Effect of dietary copper and zinc levels on tissue copper, zinc, and iron in male rats. Biol Trace Elem Res 1985;8:123-36.

17. Huang YL, Lu L, Li SF, Luo XG, Liu B. Relative bioavailabilities of organic zinc sources with different chelation strengths for broilers fed a conventional corn-soybean meal diet. J Anim Sci 2009;87: 2038-46.

18. Wang Y, Tang JW, Ma WQ, Feng J. Dietary zinc glycine chelate on growth performance, tissue mineral concentrations, and serum enzyme activity in weanling piglets. Biol Trace Elem Res 2010;133:325-34.

19. Liu Y, Ma YL, Zhao JM, Vazquez-Añón M, Stein HH. Digestibility and retention of zinc, copper, manganese, iron, calcium, and phosphorus in pigs fed diets containing inorganic or organic minerals. J Anim Sci 2014;92:3407-15.

20. Yazdankhah S, Rudi K, Bernhoft A. Zinc and copper in animal feeddevelopment of resistance and co-resistance to antimicrobial agents in bacteria of animal origin. Microb Ecol Health Dis 2014;25.

21. Sun JY, Wang JF, Zi NT, Jing MY, Weng XY. Effects of zinc supplementation and deficiency on bone metabolism and related gene expression in rat. Biol Trace Elem Res 2011;143:394-402.
22. Prins HJ, Braat AK, Gawlitta D, et al. In vitro induction of alkaline phosphatase levels predicts in vivo bone forming capacity of human bone marrow stromal cells. Stem Cell Res 2014;12:428-40.

23. Jing MY, Sun JY, Wang JF. The effect of peripheral administration of zinc on food intake in rats fed $\mathrm{Zn}$-adequate or $\mathrm{Zn}$-deficient diets. Biol Trace Elem Res 2008;124:144-56.

24. Camps J, Bargallo T, Gimenez A, et al. Relationship between hepatic lipid peroxidation and fibrogenesis in carbon tetrachloride-treated rats: effect of zinc administration. Clin Sci (Lond) 1992;83:695-700.

25. Martin RE, Mahan DC, Hill GM, Link JE, Jolliff JS. Effect of dietary organic microminerals on starter pig performance, tissue mineral concentrations, and liver and plasma enzyme activities. J Anim Sci 2011;89:1042-55.

26. Webb C, Twedt D. Oxidative stress and liver disease. Vet Clin North Am Small Anim Pract 2008;38:125-35.

27. Zalewska M, Trefon J, Milnerowicz H. The role of metallothionein interactions with other proteins. Proteomics 2014;14:1343-56.

28. Souza KL, Gurgul-Convey E, Elsner M, Lenzen S. Interaction between pro-inflammatory and anti-inflammatory cytokines in insulin-producing cells. J Endocrinol 2008;197:139-50.

29. Mendel I, Shevach EM. The IL-10-producing competence of Th2 cells generated in vitro is IL-4 dependent. Eur J Immunol 2002;32:3216-24.

30. Noben-Trauth N, Hu-Li J, Paul WE. Conventional, naive CD4 ${ }^{+} \mathrm{T}$ cells provide an initial source of IL- 4 during Th2 differentiation. J Immunol 2000;165:3620-5. 